\title{
DISTRIBUTION PATTERN, NEST-TREE FEATURES AND BREEDING PERFORMANCE OF POPULATION OF THE BLACK STORK, CICONIA NIGRA (CICONIIFORMES, CICONIIDAE), IN NORTHWESTERN SERBIA
}

\author{
D. Z. Rajković \\ Šumadijska 18, Novi Sad, 21000 Republic of Serbia \\ E-mail: strix.draze@gmail.com
}

https://orcid.org/0000-0002-2626-0076

\begin{abstract}
Distribution Pattern, Nest-Tree Features and Breeding Performance of Population of the Black Stork, Ciconia nigra (Ciconiiformes, Ciconiidae), in Northwestern Serbia. Rajković, D. Z. - Distribution pattern, nest-tree characteristics and reproductive features of Black Stork's population were evaluated in the floodplains of Gornje Podunavlje in Northwestern Serbia over five consecutive years. In total, 44 different nests were discovered and monitored. Nests were mostly placed on wide-diameter European Oaks and White Poplars between 5.5 and $18 \mathrm{~m}$ above ground level. Annually, the number of occupied nests varied between 26 and 16 with the declining trend over study years. The mean nesting density was $9.8 \pm 2$ occupied nests per $100 \mathrm{~km}^{2}$. Through study area, occupied nests were uniformly distributed and very isolated concerning the conspecific pairs. Predominantly, Black Stork preferred to nest on the lateral branches of the autochthonous mature trees with straight trunks and extensive crowns. These results suggest that the existence of old native forest stands represent crucial microhabitat criteria in the choice of the particular nesting site. In almost half of successful nesting cases, the most frequent number of fledglings was three. Overall productivity was relatively low with some variations between years implying poor nesting success. Key words: Black Stork, Ciconia nigra, breeding, Gornje Podunavlje, productivity, nesting success.
\end{abstract}

\section{Introduction}

There is a sizeable and hardly conceivable quantity of wildlife surveys and various monitoring schemes across the world. These programmes are principally designed to provide data sets to help to understand the fundamental parameters in population ecology such as abundance, spatial distribution, dispersion and population trend (Kleewein, 1999; Krebs, 2014). Mentioned parameters directly depend on the balance between fecundity, mortality, immigration and emigration (Siriwardena et al., 2000). Among them, breeding performance (fecundity) is a supremely important process underlying individual fitness and population tenacity (Etterson et al., 2011). Thus, storing, analysing and interpreting collected information represents one of the inevitable questions in population ecology and reproductive biology. In threatened, keystone and umbrella species, possession of the mentioned information are especially valuable because they may be utilised for conservation and management purposes (Witmer, 2005), or to determine the composition of communities, their structure, and ecosystem processes (Roberge \& Angelstam, 2004). The Black Stork Ciconia nigra (L., 1758) is widely recognised as an imperilled, umbrella species due to large foraging range, and its specific requirements for food and nesting sites (Roberge \& Angelstam, 2004; Moreno-Opo et al., 2011). 
In general, the Black Stork population has been well studied, at least in most European countries especially in the last two decades. In particular, aspects of the species habitat selection and use (Augutis \& Sinkevičius, 2005; Lõhmus et al., 2005), nesting sites (Treinys et al., 2008; Vlachos et al., 2008) and breeding performances (Strazds, 2011; Tamás, 2012; Alexandrou et al., 2016; Fraissinet et al., 2018) has gained noticeable attention. Diet, foraging strategies and migration pattern have also been the focus of a few studies (Hampl et al., 2005; Tamás \& Kalocsa, 2006; Bobek et al., 2008). Unfortunately, peer-reviewed papers relating to this species from Western Balkan countries, including Serbia, are scarce or completely lacking. To date, seven articles have been published respectively (Marčetić, 1957; Popović, 1960; Puzović et al.,1988/89; Schneider-Jacoby, 1999; Erg, 2002; Tucakov et al., 2006; Velevski et al., 2008). All of them are considerably varied in the quality of data and analyses mostly turned to general information and preliminary studies while more specific and comprehensive data are missing.

In that context, the principal goal of this study is to increase general knowledge and obtain meaningful data on the reproductive biology and ecological requirements of the poorly studied Black Stork population in Serbia and adjacent areas (except Hungary). Hence, the aims of this study were (i) to estimate abundance, density and short-term trend, (ii) to describe the distribution pattern and characteristics of nests, and (iii) to evaluate the variation in the breeding performance of Black Stork population over five research years (2011-2015).

\section{Material and methods}

\section{Study area}

Alluvial flood plains represent one of the most remarkable habitats for the Black Stork population survival in Europe (Sackl \& Strazds, 1997; Kalocsa \& Tamás, 2002). In whole Europe, one of the most outstanding area for this sensitive species lies along the intermediate course of the Danube River, from the mouth of the Sio channel in Hungary downstream to the mouth of the Drava in Croatia covering approximately $750 \mathrm{~km}^{2}$ of wetlands (Tamás, 2012). This vast periodically flooded landscape is separated into three administrative parts by country borders - Croatia, Hungary, and Serbia. The research took place on the Serbian side (left Danube bank) in Vojvodina Province where lies "Gornje Podunavlje" Special Nature Reserve. It has an irregular and elongated shape stretched along 1.367-1.433 Danube river km and consists of two swampy areas - Monoštor and Apatin. Together with several detached forest fragments outside of natural reserve borders study area in total cover $201 \mathrm{~km}^{2}$, respectively. Deciduous forest stands cover at least $50 \%$ of the study area. The White Willow (Salix alba L., 1758), the White and the Black poplar (Populus alba L., 1758 and P. nigra L., 1758) and European Oak (Quercus robur L., 1758), are the most prevalent tree species (Stojanović et al., 2014). Besides natural and seminatural forest stands, substantial parts are covered with plantations of allochthonous tree species, mainly hybrids of rapid-growing poplars (Tucakov et al., 2006). In general, the study area is flat, $80-90 \mathrm{~m}$ above sea level and has a temperate continental climate with warm summers and icy winters. Consequently, the warmest month is July (average $21.9^{\circ} \mathrm{C}$ ) while the coldest month of the year is January $\left(-0.1^{\circ} \mathrm{C}\right)$. Mean annual precipitation is $612.4 \mathrm{~mm}$ with the smallest sum in February $(29.9 \mathrm{~mm})$ and the greatest in June (81.5 mm; Stojanović, 2018).

\section{Fieldwork and data collection}

The data referred to this article have been collected through extensive field surveys carried out in five breeding seasons, from January of 2011 to May of 2015 in the alluvial forests of Northwestern Serbia. In the whole territory of the research area, data collection includes abundance, distribution, characteristics of the nesting tree, breeding habits, reproductive success, and when it is possible nest failures. Yet, due to lack of funding, research coverage during 2015 was highly reduced to data on controlled and occupied nests. The description of terms regarded to reproduction follows the terminology recommended by Steenhof et al., (2017).

Initially, the Black Stork territories and nests were located and mapped through inquiries address to fieldoriented professions in the area: foresters and reserve rangers. The author with colleagues also took part in the active search for nests. These field excursions were primarily conducted in February, March and April. Surveys were undertaken by off-road vehicles and on foot. Surveys during a winter-spring period are more appropriate than those in other seasons because large Black Stork's stick nests are often remarkably exposed in a deciduous forest without leaves and also because there is no risk of disturbance (Puzović et al., 1988/89; Tamás, 2012). Additionally, in late March and through April, the study area was scanned by binoculars from prominent points. The beginning of spring is a time when Black Storks are building or repairing their nest and when they display territorial behaviour. Territorial birds were distinguished from floaters by performing a conspicuous aerial courtship display close to nesting eyries mostly around the midday (Schneider-Jacoby, 1999; Sackl, 2000). After locating territorial birds, they were followed from a distance in hope to reveal breeding eyrie or exact location of the nest. Both ways of searches for nests were conducted every winter/spring period and occasionally throughout the whole year to supplement targeted search. If formerly known nests are unoccupied, but Black Storks are observed in close vicinity, a search for an alternative nest(s) was conducted. During the mapping process, details of each discovered nest were written in field protocol and georeferenced by a hand-held GPS device (Garmin GPSmap $62 \mathrm{~s}$ ). For every discovered nest, the following data were recorded: the tree species, placement position, and height of the nest base measured from the ground point. Classification of nest placement was according to their position on the nesting tree (Tamás, 2012). Type 1: nest is in the main pitchfork of the tree; type 2: nest is on the horizontal branches, leaned or near $(<1.5 \mathrm{~m})$ to the tree trunk; type 3 : nest is on the horizontal branches more than $1.5 \mathrm{~m}$ 
distant from the tree trunk; and type 4: nest is on the horizontal tree trunk bent by a wind storm. Measurements of nest heights were performed with a ribbon after climbing on nest platform during mid June-early July. In order to describe each nest-tree characteristics, the following information were recorded: general position (interior, edge $\leq 40 \mathrm{~m}$ from clearing or road, or solitary), trunk shape (straight, slightly crooked, crooked, or forked), diameter at breast height (DBH) and crown class (dominant, codominant, intermediate, or suppressed). Nest-tree characteristics and associated measurements were performed according to the instructions of USDA Forest Service (2006).

After the nest was found, it checked at least once, usually during the April or rarely on the beginning of May to determine it is occupied or not. This early check was always carried out from a safe distance to avoid disturbance and during favourable weather conditions. The nest is considered as occupied if fresh building material was added (e. g. new twigs) or at least one adult bird was observed perching/incubating on the nest platform or in the proximity (Lõhmus et al., 2005; Tamás, 2012). All occupied nests were re-visited at least once in June-early July, to determine the nesting success in the pre-fledgling period. In cases when it was possible nest failure causes were recorded. Nesting failures were determined by obvious clues that indicate human presence or predator activity, such as footprints of feathers recorded on nest substratum.

Finally, the distribution pattern of the Black Stork nests was expressed through the nearest neighbour distance index (Clark \& Evans, 1954) and isolation index (Carrete et al., 2006). The nearest neighbour distance index $(R)$ has a limited range with the value indicative of perfectly uniform $(R>1)$, random $(R=1)$ and wholly aggregated $(\mathrm{R}=0)$ pattern of distribution (Clark \& Evans, 1954). Isolation index $\left(\mathrm{S}_{\mathrm{i}}\right)$ ranged from 0 to 1 ; from more isolated to more connected (Carrete et al., 2006). Both indices were calculated with a set of linear distances measured to nearest $5 \mathrm{~m}$ with a combination of Google Earth Pro and QGIS version 2.18. (QGIS Development Team, 2016). Nesting density was calculated as the number of occupied nests per $100 \mathrm{~km}^{2}$. Productivity was defined as the number of well-feathered nestlings divided by the number of successful pairs. Term well-feathered nestling refers to juvenile aged about 55-70 days, respectively (Lõhmus et al., 2005; Tamás, 2012). Nesting success was determined as the mean number of well-feathered juveniles per occupied nest.

\section{Statistical analysis}

Prior to data analyses, all sample variables were examined for normality by the use of the KolmogorovSmirnov test (sample size $>50$ ), Shapiro-Wilk test (sample size $<50$ ) and normal probability plots. In all tested cases, data were not normally distributed; thus, the non-parametric techniques were applied to hypothesis testing. Mann-Whitney (U) and Kruskal-Wallis test (H) applied to verify whether the samples originate from the same distribution and $G$-test for homogeneity with Williams' correction factor $\left(G_{\text {adj }}\right)$ was used for analysing frequencies (Sokal \& Rohlf, 1995). Spearman rank correlation coefficient $\left(r_{s}\right)$ applied to check the significance of the relationship between two measured variables (Sokal \& Rohlf, 1995). All performed tests were two-tailed. Values of $p<0.05$ were accepted as significant. The measurement values are presented as arithmetic mean \pm one standard deviation. Statistical processing was performed using the IBM SPSS software version 23.0 for Windows (IBM Corporation, 2015).

\section{Results}

Distribution pattern, population trend and density

A total of 44 different nests of Black Stork were detected through five research years. The number of controlled nests was stable during the study period. However, only $6.81 \%$ $(n=3)$ of nests were continuously occupied during 2011-2015, while $2.3 \%(n=1)$ of nests during four consecutive years, $15.9 \%(n=7)$ of nests during three, $34.1 \%(n=15)$ of nests during two and $40.9 \%(\mathrm{n}=18)$ of nests were occupied during one breeding season. On average, $19.8 \pm 4( \pm 95 \% \mathrm{CI})$ pairs of the Black Stork tried to breed on the year base ranged between 16 and 26 pairs (table 1).

Nevertheless, the Black Stork population moderately decreased by 2.3 occupied nests per year suggests a precipitous declining trend in the study area $\left(\mathrm{r}_{\mathrm{s}}=-0.9, \mathrm{p}=0.037\right)$. The mean nesting density was $9.8 \pm 2( \pm 95 \% \mathrm{CI})$ occupied nests per $100 \mathrm{~km}^{2}$ of the study area. The highest concentration of occupied nests was situated in central parts of Apatin swamp (locality Jelensko ostrvo) where six different occupied nests were recorded at the surface of circa $4.3 \mathrm{~km}^{2}$ during 2011 . The spatial distribution of the occupied nests displays a uniform distribution pattern $(\mathrm{R}=1.73)$. Furthermore, the occupied nests were extremely isolated concerning the conspecific pairs $(\mathrm{Si}<0.01)$. Altogether, Black Stork pairs nested an average of 2,201.7 $\mathrm{m} \pm 2,020.2 \mathrm{~m}$ from conspecifics (range 150-9,460 m). Despite yearto-year variations, no significant difference was noted through years between a distance of the nearest neighbour $\left(\mathrm{H}_{82}=4.18, \mathrm{p}=0.242, \mathrm{df}=3\right)$. 
Table 1. Breeding parameters of a Black Stork (Ciconia nigra) population in Northwestern Serbia monitored from 2011 to 2015

\begin{tabular}{l|c|c|c|c|c|c}
\hline \multicolumn{1}{c}{ Year } & $\begin{array}{c}\text { Controlled } \\
\text { nests }\end{array}$ & $\begin{array}{c}\text { Occupied } \\
\text { nests }\end{array}$ & $\begin{array}{c}\text { Successful } \\
\text { pairs }\end{array}$ & Fledglings & Productivity & $\begin{array}{c}\text { Nesting } \\
\text { success }\end{array}$ \\
\hline 2011 & 31 & 26 & 11 & 31 & 2.81 & 1.19 \\
2012 & 32 & 21 & 4 & 8 & 2 & 0.38 \\
2013 & 36 & 19 & 9 & 24 & 2.66 & 1.26 \\
2014 & 32 & 16 & 10 & 29 & 2.9 & 1.81 \\
2015 & 33 & 17 & - & - & - & - \\
Total & - & 99 & 34 & 92 & - & - \\
Mean \pm SD & $32.8 \pm 1.9$ & $19.8 \pm 4.0$ & $8.5 \pm 3.1$ & $23 \pm 10.4$ & $2.58 \pm 0.4$ & $1.16 \pm 0.6$ \\
\hline
\end{tabular}

\section{Nest tree features}

In the study area, nests of Black Storks were placed on five tree species. Majority of the nests are constructed on the European Oak and the White Poplar (84 \%), indicating considerable preferences in the selection of tree species for nest placement by Black Stork pairs (fig. 1).

Consequently, comparison among tree species on which Black Storks built their nests shows the statistically significant difference $\left(\mathrm{G}_{\mathrm{adj}}=39.71 \mathrm{df}=4\right)$. Additionally, Black Storks avoided to nesting on solitary trees $(2.27 \%)$ and forest edges $(27.27 \%)$ and more favoured interior parts of forest stand for nest placement $(70.45 \%)$. Nests were situated on trees between 5.5 and $18 \mathrm{~m}$ above ground level $(11.2 \pm 3.3 \mathrm{~m})$. All four types of nests placement were recorded and Black Storks tended to build nests on a horizontal branch of old, mature trees $(\mathrm{DBH}=85.7 \pm 15.95 \mathrm{~cm})$. Indeed, $84.1 \%$ of nests were constructed on a lateral branch close to the tree trunk (type 2; fig. 2). Furthermore, trees with straight trunk shape were highly significantly selected for nest placement than the other three types tested $\left(\mathrm{G}_{\text {adj }}=27.91, \mathrm{df}=3\right)$. Following trunk shape, there is a significant tree selection heterogeneity between measured four crown classes $\left(\mathrm{G}_{\mathrm{adj}}=26.06 \mathrm{df}=3\right)$ where dominant and codominant tree crowns are preferred (together $84.09 \%$ ).

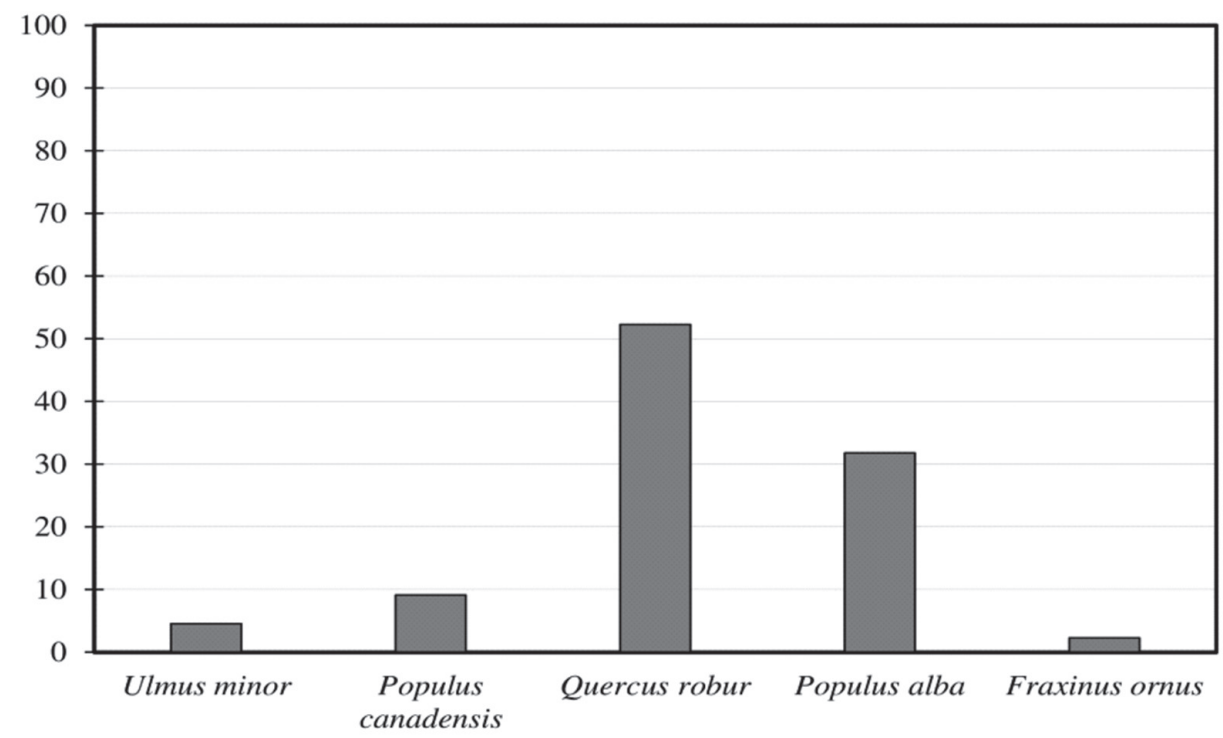

Fig. 1. The proportion of tree species picked for nest placement by the Black Stork (Ciconia nigra) in Northwestern Serbia $(n=44)$. 


\section{Breeding performance}

Depending on the year, the number of successful nesting attempts and where at least one nestling was fledged range from four to $11(8.5 \pm 3.1)$. It means that between 24 and $39 \%$ of occupied nests did not produce any fledglings (table 1). In almost half of successful nesting cases, the most frequent number of fledglings was three (47.06 \%). However, within the study area, productivity did not vary between years $\left(\mathrm{H}_{34}=1.48, \mathrm{p}=0.69, \mathrm{df}=3\right)$. The share of successful pairs which build new nests was a slightly higher than for those who reused last year's nest (55.6 vs. $44.4 \%$ ). There was

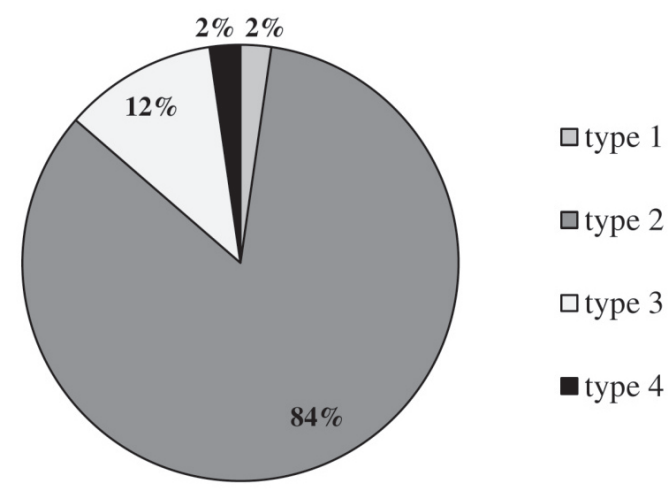

Fig. 2. The ratio of Black Stork's (Ciconia nigra) nest placement types in the Northwestern Serbia $(n=44)$. no statistically significant distinction in nesting success between reused and newly built nests $\left(\mathrm{U}_{56}=205, \mathrm{z}=-0.97, \mathrm{p}=0.33\right)$. Average annual productivity of Black Storks was moderately negatively, but not significantly correlated to the annual number of occupied nests $\left(r_{s}=-0.4\right.$, $\mathrm{p}=0.6$ ). Altogether, the overall productivity does not correlate with distance to the nearest occupied nest $\left(\mathrm{r}_{\mathrm{s}}<-0.01, \mathrm{p}=0.97\right)$. Principally, it means that the number of fledglings per occupied nest was stable regardless of whether the nearest neighbour is relatively close or distant. Out of 48 unsuccessful attempts, in only seven cases (14.6\%) the cause of nest failures was undoubtedly known. In three cases, the nest failed due to direct human disturbance during the incubation stage, and four nests were placed under predation.

\section{Discussion}

Woodlands along Upper Danube flow has always been considered as the most important breeding ground of Black Stork in Serbia. Indeed, the presented study confirmed this general statement. Depending on the year, between 10.5 and $17.1 \%$ of the national population of Black Storks bred in Gornje Podunavlje area. Taking into account the possibility of a few overlooked eyries in remote flooded parts, the results indicate existence between 19 and 27 occupied eyries per year during the study period. According to the previously done Important Bird Area (IBA) assessments, the nesting population of Black Storks of Gornje Podunavlje was estimated on 35-45 and 30-40 pairs (Puzović \& Grubač, 2000). At least during the study period, it has been shown that these optimistic estimations are not valid. In contrast to IBA assessment, Tucakov et al., (2006) found 15 nesting pairs in the Gornje Podunavlje for the equivalent period. The data concerning relatively poor re-occupancy of nests can be explained by high mortality of adults, low nest site fidelity or influence some factor that forces birds to shift location like regular predation or human disturbance. The first two reasons seem unrealistic, especially keeping in mind that adult individuals of Black Storks have relatively high survival rate and strong site fidelity (Tamás, 2012). Also, adult Black Storks have almost no natural enemies; so, this factor can be rejected too. At the same time, the study area is subject to very intensive forest management with a strong network of forest roads. Forestry activities begin growing after the snow melts (beginning of March) and reach significant intensity during April and May. Hence, the time frame of forestry operations coincides with the period of courtship, nest reparation and incubation of Black Storks. Thus, forestry and other human activities might partly explain the poor re-occupancy rate of the nest and consequently may have implications on productivity and nesting success. Several other studies have confirmed that Black Stork is disturbancesensitive species especially regarding forestry operations near nesting site (Puzović et al., 1988/89; Lõhmus et al., 2005; Strazds, 2011). 
Many large birds, including Black Stork, are typical K-selected species, which have a large body, long lifespan, produce fewer offspring that requires prolonging parental care and reach maturity relatively late (MacArthur \& Wilson, 2001). K-selected species are usually constant in numbers and close to the maximum that the environment can carry. However, the result obtained in this study shows the declining short-term trend of Black Stork breeding population in the investigated area. The apparent reasons for the reduction in the number of mature individuals in Gornje Podunavlje are uncertain. Several published studies have addressed that breeding population decline or significant annual fluctuations might be linked to the lack of mating partners, especially females (Konovalov et al., 2019), poaching during major migration routes (Campbell \& Veríssimo, 2015) or unfavourable ecological conditions on winter grounds (Saino et al., 2004). Furthermore, electrocution may also influence fluctuations and decline in numbers of sexually mature individuals at least on the local level (Kalocsa \& Tamás, 2018). Also, a factor that may results population decline is decreasing density of breeding pairs as a consequence of poor reproduction in the past (Lõhmus et al., 2005), which in the end can lead to genetic deterioration and reduced fertility in adults (Burgman et al., 1988). Extensive changing of the breeding regions or adult starvation is unlikely because populations in neighbouring Hungary and Croatia are stable and no significant reduction in food resources was recorded (Tamás, 2012).

Despite annual differences and some local nest aggregations, it seems that spatial distribution of the Black Stork in Gornje Podunavlje was continual throughout the entire area. The moderately high mean nesting density of $\sim 10$ per $100 \mathrm{~km}^{2}$ is twice lower than recorded just across the border in Gemenc area in Hungary (Kalocsa \& Tamás, 2006), but in the end typically for this trans-boundary alluvial area and much higher than in rest of Europe (Tamás, 2012). On the local level, it is interesting that the high density of occupied nests on Apatin swamp in this study was also recorded during 1996 when seven pairs of Black Storks bred on the surface of $1.53 \mathrm{~km}^{2}$ (S. Puzović personal communication in Tamás, 2012). Thus, native forest stands in the heart of Apatinski rit provides optimal conditions for nesting, that is not only temporarily, but also probably is constant, at least for the last two decades. Earlier results from Serbia, Hungary, and Croatia are also pointing the importance of old native forest stands of European Oaks and White Poplars for nest placement (Puzović et al., 1988/89; Tucakov et al., 2006; Tamás, 2012). In mentioned studies and this study as well, over $80 \%$ of nests were built on these two tree species highlights the affinity towards autochthonous stands with well-developed crowns. In opposite, just a few nests were situated on the hybrid poplars indicating that the Black Storks avoids plantations and has the low ability of adaptation to intensively managed forests. The reasons for avoiding plantations of fast-growing Poplars during breeding could be numerous. Yet, they are probably connected with homogeneity of plantation structure like spatial layout, tree density and branch-foliage characteristics followed by intensive management and frequent human presence in comparison with natural stands (Calladine et al., 2018). Other possibilities including nest visibility, which could be essential in protection from avian predators and enough free space around the nest as an important factor during copulation and landing (Strazds, 2011). However, the obtained results once again confirm that breeding pairs of Black Storks are an excellent indicator of the existence of mature forest stands (Treinys et al., 2008; Tamás, 2012). Strong preference towards the European Oak has also been recorded in higher geographical latitudes of the European continent, although in those areas mixed and coniferous forests were dominated forest types (Czuchnowski \& Profus, 2008; Treinys et al., 2009; Strazds, 2011). Nest heights and DBH found in this study are largely coinciding to those found previously in Serbia (Puzović et al., 1988/89; Tucakov et al., 2006) and other European countries (Lõhmus \& Sellis, 2003; Strazds, 2011; Tamás, 2012). Conversely, nest position on the tree is significantly different in comparison to those analysed in the Hungarian part of Danube (Tamás, 2012). This could be simply due to different supply of forest stands in the field and their general habitus. Another possibility is a kind 
Table 2. Productivity and nesting success of the Black Stork (Ciconia nigra) published in different European studies

\begin{tabular}{l|c|c|c}
\hline \multicolumn{1}{c}{ Country } & Productivity & Nesting success & Source \\
\hline Estonia & 2.40 & 1.09 & Sellis, 2000 \\
Spain & 2.53 & 2.33 & Cano Alonso \& Fernandez, 2003 \\
Cze. Republic & 3.29 & - & Pojer, 2003 \\
Latvia & 2.66 & 1.81 & Strazds, 2011 \\
Hungary & 2.63 & - & Tamás, 2012 \\
Greece & 3.26 & - & Alexandrou et al., 2016 \\
Italy & 3.06 & 2.31 & Fraissinet et al., 2018 \\
Serbia & 2.58 & 1.16 & this study \\
\hline
\end{tabular}

of trade between favourable tree features and safety of nesting location in terms of human disturbance (Strazds, 2011). In addition to the importance of Oaks and White Poplar trees, in microhabitat scale, a preference to interior forest stands is another considerable feature of Black Stork nest stands in the study area. This finding is consistent with previously obtained studies (Treinys et al., 2009; Tamás, 2012).

The Black Stork's population in the study area exhibit similar symptoms as many other declining bird populations, including lowered or fluctuated productivity and poor nesting success (Newton, 2004). Various abiotic and biotic factors such as weather conditions or human disturbance are strongly influencing the productivity and nesting success of the Black Stork (Kalocsa \& Tamás, 2002; Tamás, 2012). The obtained negative correlation between annual productivity and abundance in occupied nests could be assumed. The roots of this assumption lie in carrying capacity of a natural environment and quality of individual breeding territory (Newton, 1998). Hence, an increase in abundance and density of Black Stork pairs lead to the occupation of territories with poorer general conditions and consequently to the lower productivity and nesting success. The latter parameter will frequently be the first one to signalise the growing impact of threats and failures (Väli, 2015). In the presented study, the nesting success of the Black Stork is rather low compared to the other European studies (table 2) and together with declining population trend calls for concern.

In neighbouring Hungary, water level and the existence of shallow water bodies as foraging grounds dictate the amount of food availability, which is one of the main determinants of nesting success (Newton, 1998; Tamás, 2012). Thus, quality of foraging habitat, food availability and prey dynamics may adequately explain poor nesting success in the studied area, at least to some extent. Besides, understanding the reasons that affect the nest success may help identify factors contributing to obtained population declines in general. In the present study, it was impossible to determine the reasons for nest failures in more than $85 \%$ of cases. Consequently, it is impossible to draw any conclusions or regularity about failures; thus, key drivers that influenced low productivity and nesting success remain rather unclear. Therefore, further research is needed to understand better these ecological processes and fill many gaps in our understanding of the ecology of the Black Stork population in the Gornje Podunavlje floodplains. Lastly, because of the high population ratio at the country level and its rarity, conservation measures based on scientific evidence and well-designed strategies are highly recommended, in order to protect one of the strongholds of Black Stork population in Serbia and this part of Europe.

\section{Conclusions}

The Black Stork is a regular and relatively common breeding species in the floodplains along the Danube in Northwestern Serbia. This extensive study demonstrates once again that Black Stork is a good indicator species of old, mature trees inside native forest stands. 
Presented data showed a strong preference to mature, large-diameter European Oak and White Poplar as host tree species for nest placement and avoidance of a plantation of hybrid Poplars. Despite its high breeding density, the obtained data suggest declining short-term trend and very likely long-term trend based on published estimations in the last decades. The pattern of population decline runs closely parallel to the productivity fluctuations and low nesting success, but the reasons remain unclear and speculative.

The study of breeding Black Stork's population in Gornje Podunavlje would not have been possible without the financial and logistic support of Public Enterprises "Vojvodinašume" (Forest holding "Sombor” from Sombor) and their dedicated employees Milan Rajić, Radmila Šakić Peurača, Biljana Latić, Ivan Blažev, Đuro Ratković, Željko Krtinić which support and contribution were irreplaceable and essential. Besides, the author owes gratitude to Milan Ružić and Draško Grujić for assistance during fieldwork. Dimitrije Radišić and Saša Rajkov have done GIS data processing. Kristina Floigl, Anna Enikő Tamás and Thomas Oliver Mérö reviewed the initial manuscript and improved the English. During 2014, the survey and monitoring activities were supported by the grant of European Union through a project "Wildlife health and conservation of selected NATURA 2000 species within the Danube Cross-border region in Serbia and Hungary (Wildcond) - HUSRB/1203/122/224-02".

\section{References}

Alexandrou, O., Bakaloudis, D. E., Papakosta, M. A., Vlachos, C. G. 2016. Breeding density, spacing of nest-sites and breeding performance of black storks Ciconia nigra in Dadia-Lefkimi-Soufli Forest National Park, north-eastern Greece. North-western Journal of Zoology, 12 (1), 7-13.

Augutis, D., Sinkevičius, S. 2005. Application of Geographic Information System (GIS) technologies in identification of potential nesting habitats of black stork (Ciconia nigra). Acta Zoologica Lituanica, 15 (1), 3-12. Doi: 10.1080/13921657.2005.10512603

Bobek, M., Hampl, R., Peške, L., Pojer, F., Šimek, J., Bureš, S. 2008. African Odyssey project-satellite tracking of black storks Ciconia nigra breeding at a migratory divide. Journal of Avian Biology, 39 (5), 500-506. Doi: 10.1111/j.0908-8857.2008.04285.x

Burgman, M. A., Akcakaya, H. R., Loew, S. S. 1988. The use of extinction models for species conservation. Biological Conservation, 43 (1), 9-25. Doi: 10.1016/0006-3207(88)90075-4

Calladine, J., Díaz, M., Reino, L., Jardine, D., Wilson, M. 2018. Plantations of Non-native Tree Species. In: Mikusiński, G., Roberge, J., Fuller, R., eds. Ecology and Conservation of Forest Birds (Ecology, Biodiversity and Conservation). Cambridge University Press, Cambridge, UK, 350-386. Doi: $10.1017 / 9781139680363.013$

Campbell, B., Veríssimo, D. 2015. Black Stork Down: Military Discourse in Bird Conservation in Malta. Human Ecology, 43 (1), 79-92. Doi: 10.1007/s10745-015-9724-6

Cano Alonso, L. S., Fernandez, M. 2003. The Black Stork Ciconia nigra in Madrid region: status, population changes and reproduction. Aves, 40, 38-43.

Carrete, M., Sánchez-Zapata, J. A., Tella, J. L., Gil-Sánchez, J. M., Moleón, M. 2006. Components of breeding performance in two competing species: habitat heterogeneity, individual quality and density-dependence. Oikos, 112 (3), 680-690. Doi: 10.1111/j.0030-1299.2006.14528.x

Clark, P. J., Evans, F. C. 1954. Distance to nearest neighbor as a measure of spatial relationships in populations. Ecology, 35, 445-453. Doi: 10.2307/1931034

Czuchnowski, R., Profus, P. 2008. Distribution, changes in numbers, and breeding biology of the Black Stork Ciconia nigra in Poland. Biota, 9, 5-14.

Erg, B. 2002. Influence of three-levelled zonation of protection of Special Nature Reserve Gornje Podunavlje for protection of Black Stork and White-tailed Eagle nests within area Kanlija Pesak. Ciconia, 11, 80-85 [In Serbian].

Etterson, M. A., Ellis-Felege, S. N., Evers, D., Gauthier, G., Grzybowski, J. A., Mattsson, B. J., Nagy, L. R., Olsen, B. J., Pease, C. M., van der Burg, M. P., Potvien, A. 2011. Modelling fecundity in birds: Conceptual overview, current models, and considerations for future developments. Ecological Modelling, 222 (14), 2178-2190. Doi: 10.1016/j.ecolmodel.2010.10.013

Fraissinet, M., Bordignon, L., Brunelli, M., Caldarella, M., Cripezzi, E., Giustino, S., Mallia, E., Marrese, M., Norante, N., Urso, S., Visceglia, M. 2018. Breeding population of Black Stork, Ciconia nigra, in Italy between 1994 and 2016. Rivista Italiana di Ornitologia - Research in Ornithology, 88 (1), 15-22. Doi: $10.4081 /$ rio. 2018.345

Hampl, R., Bureš, S., Baláž, P., Bobek, M., Pojer, F. 2005. Food provisioning and nestling diet of the black stork in the Czech Republic. Waterbirds, 28 (1), 35-40. Doi: 10.1675/1524-4695(2005)028[0035:FPANDO]2.0.CO;2

IBM Corporation, 2015. IBM SPSS Statistics for Windows, Version 23.0. Armonk, NY, USA.

Kalocsa, B., Tamás, E. A. 2002. Survey of the Black Stork (Ciconia nigra) population in the Gemenc forest. Nesting habits and breeding efficiency (1992-2000). Aquila, 107-108, 215-223 [In Hungarian]. 
Kalocsa, B., Tamás, E. A. 2006. An analysis of nesting data of Black Storks Ciconia nigra in the Gemenc region of the Danube-Drava National Park (1992-2003). Biota, 7 (1-2), 47-50.

Kalocsa, B., Tamás, E. A. 2018. The Hazards of Overhead Electric Lines on Black Storks. In: Cano Alonso, L. S., Sundar, K. S. G. eds. VII International Conference on Black Stork Ciconia nigra: Programme and abstracts book. IUCNSSC Stork, Ibis and Spoonbill Specialist Group Special Publication 1. Seville Spain and Mysuru India, 21.

Kleewein, D. 1999. Population size, density, spatial distribution and dispersal in an Austrian population of the Land Snail Arianta arbustorum styriaca (Gastropoda: Helicidae). Journal of Moluscan Studies, 65, 303-315. Doi: 10.1093/mollus/65.3.303

Konovalov, A., Nellis, R., Nurmla, A., Sellis, U., Väli, Ü. 2019. Solitude at periphery: lack of partners limits reproduction of the Black Stork (Ciconia nigra) at the margin of the distribution range. Ornis Fennica, 96, 13-23.

Krebs, C. J. 2014. Ecology: The Experimental Analysis of Distribution and Abundance. Sixth edition. Pearson Education Limited, Essex, UK, 1-646.

Lõhmus, A., Sellis, U. 2003. Nest trees - a limiting factor for the Black Stork Ciconia nigra populations in Estonia. Aves, 40 (1-4), 84-91.

Lõhmus, A., Sellis, U., Rosenvald, R. 2005. Have recent changes in forest structure reduced the Estonian black stork Ciconia nigra population? Biodiversity and Conservation, 14 (6), 1421-1432. Doi: 10.1007/s10531004-9667-5

MacArthur, R. H., Wilson, E. O. 2001. The Theory of Island Biogeography. Second edition. Princeton University Press, Princeton, US, 1-203.

Marčetić, M. 1957. Black Stork, Ciconia nigra, in Vojvodina. Larus, 9/10, 172-175.

Moreno-Opo, R., Fernández-Olalla, M., Guil, F., Arredondo, A., Higuero, R., Martín, M., Soria, C., Guzmán, J. 2011. The role of ponds as feeding habitat for an umbrella species: best management practices for the black stork Ciconia nigra in Spain. Oryx, 45 (3): 448-455. Doi: 10.1017/S0030605310001560

Netwon, I. 1998. Population limitation in birds. Academic Press, London, UK, 1-597.

Newton, I. 2004. The recent declines of farmland bird populations in Britain: an appraisal of causal factors and conservation actions. Ibis, 146,: 579-600.

Pojer, F. 2003. Black Stork (Ciconia nigra) in the Czech Republic: Present' Status and Conservation. Aves, 40 (1-4), 20-24.

Popović, J. 1960. Refuge of White-tailed Eagle (Haliaetus albicilla L.) and Black Stork (Ciconia nigra L.) in surrounding of Bački Monoštor village. Zaštita prirode, 18/19, 88-91 [In Serbian].

Puzović, S., Sekulić, V., Pavlović, D. 1988/89. Black Stork (Ciconia nigra L.) at the Obedska bara 1983-1987. Bulletin of Natural History Museum B, 43-44, 161-174 [In Serbian].

Puzović, S., Grubač, B. 2000. Federal Republic of Yugoslavia. In: Heath, M. F., Evans, M. I., eds. Important Bird Areas in Europe: Priority sites for conservation. Second part (Southern Europe). BirdLife International, Cambridge, UK, 725-745.

QGIS Development Team, 2016. QGIS Geographic Information System. Open Source Geospatial Foundation Project. http://qgis.osgeo.org

Roberge, J-M., Angelstam, P. 2004. Usefulness of the Umbrella Species Concept as a Conservation Tool. Conservation Biology, 18 (1), 76-85. Doi: 10.1111/j.1523-1739.2004.00450.x

Saino, N., Szép, T., Romano, M., Rubolini, D., Spina, F., Møller, A.P. 2004. Ecological conditions during winter predict arrival date at the breeding quarters in a trans-Saharan migratory bird. Ecology Letters, 7, 21-25. Doi: 10.1046/j.1461-0248.2003.00553.x

Sackl, P. 2000. Form and function of aerial courtship displays in Black Storks Ciconia nigra. Acrocephalus, 21 (102-103), 223-229.

Sackl, P., Strazds, M. 1997. Ciconia nigra Black Stork. In: Hagemeijer, E. J. M., Blair, M. J., eds. The EBCC Atlas of European Breeding Birds: Their Distribution and Abundance. T \& A D Poyser, London, UK, 56-57.

Schneider-Jacoby, M. 1999. Values of the Lonjsko Polje Nature Park and the Sava Wetlands. Bilten parka prirode Lonjsko Polje, 1, 21-27.

Sellis, U. 2000. Will the Black Stork remain to breed in Estonia? Hirundo, 13 (1), 19-30 [In Estonian].

Siriwardena, G. M., Baillie, S. R., Crick, H. Q. P., Wilson, J. D. 2000. The importance of variation in the breeding performance of seed-eating birds in determining their population trends on farmland. Journal of Applied Ecology, 37 (1), 128-148. Doi: 10.1046/j.1365-2664.2000.00484.x

Sokal, R. R., Rohlf, F. J. 1995. Biometry: The Principles and Practices of Statistics in Biological Research. Third Edition. W. H. Freeman and Company, New York, USA, 1-850.

Steenhof, K., Kochert, M. N., McIntyre, C. L., Brown, J. L. 2017. Coming to terms about describing Golden Eagle reproduction. Journal of Raptor Research, 51 (3), 378-390. Doi: 10.3356/JRR-16-46.1

Stojanović, V., Velojić, M., Šakić, R. 2014. Sustainable tourism development strategy in the "Gornje Podunavlje" Special Nature Reserve. Public Enterprise "Vojvodinašume", Forestry "Sombor", Sombor, Serbia, 1-31 [In Serbian].

Strazds, M. 2011. Conservation Ecology of the Black Stork in Latvia. PhD thesis, Faculty of Biology, University of Latvia, Riga, 1-96. 
Tamás, E. A. 2012. Breeding and migration of the Black Stork (Ciconia nigra), with special regard to a Central European population and the impact of hydro-meteorogical factors and wetland status. PhD thesis, JuhásNagy Pál Doctoral School, University of Debrecen, Debrecen, 1-146.

Tamás, E. A., Kalocsa, B. 2006. The diet of young and feeding places of adult's Black Storks Ciconia nigra in Gemenc. Biota, 7 (1-2), 103-107.

Treinys, R., Lõhmus, A., Stončius, D., Skuja, S., Drobelis, E., Šablevičius, B., Rumbutis, S., Dementavičius, D., Naruševičius, V., Petraška, A., Augutis, D. 2008. At the border of ecological change: status and nest sites of the Lithuanian Black Stork Ciconia nigra population 2000-2006 versus 1976-1992. Journal of Ornithology, 149, 75-81. Doi: 10.1007/s10336-007-0220-7

Treinys, R., Stončius, D., Augutis, D., Skuja, S. 2009. Breeding habitat of the Black Stork Ciconia nigra in Lithuania: implications for conservation planning. Baltic Forestry, 15 (1), 33-40.

Tucakov, M., Kalocsa, B., Mikuska, T., Tamás, E.A., Žuljević, A., Erg, B., Deme, T. 2006. The Black Stork Ciconia nigra between the Sió channel and the Drava river in the central Danube floodplain: transboundary monitoring and protection plan. Biota, 7 (1-2), 109-118.

Väli, Ü. 2015. Monitoring of spotted eagles in Estonia in 1994-2014: Stability of the lesser spotted eagle (Aquila pomarina) and decline of the greater spotted eagle (A. clanga). Slovak Raptor Journal, 9, 55-64. Doi: 10.1515/srj-2015-0004

Velevski, M., Grubač, B., Hallmann, B. 2008. Distribution and estimation of the population size of the Black Stork Ciconia nigra in Macedonia. Ciconia, 17, 14-19.

Vlachos, C. G., Bakaloudis, D. E., Alexandrou, O. G., Bontzorlos, V. A., Papakosta, M. A. 2008. Factors affecting the nest-site selection of the black stork, Ciconia nigra in the Dadia-Lefkimi-Soufli National Park, northeastern Greece. Folia Zoologica, 57 (3), 251-257.

USDA FOREST SERVICE 2006. Forest inventory and analysis national core field guide, Vol. 1: Field data collection procedures for phase 2 plots. National Core Field Guide. Version 3.1. USDA Forest Service, Forest Inventory and Analysis (FIA), Washington, DC, 2-294.

Witmer, G. W. 2005. Wildlife population monitoring: some practical considerations. Wildlife Research, 32 (3), 259-263. Doi: 10.1071/wr04003

Received 23 November 2020

Accepted 3 March 2021 